\title{
GEOLOGICAL AND HYDROGEOLOGICAL EFFECTIVE FACTORS IN THE HIGH PERMEABILITY ZONES OF SEVERAL DAM SITES OF THE ZAGROS REGION, IRAN
}

\author{
Behnaz Shabab Boroujeni ${ }^{1}$, Javad Ashjari² and Haji Karimi ${ }^{3}$
}

\begin{abstract}
Stratigraphical, discontinuity and hydraulic characteristics of a karstic region are crucial factors in solution development, producing areas with strong contrasts in permeability with probable water seepage from dam foundations and abutments. The aim of this study is to explore the effect of these elements on karstic dam sites of the Zagros region in Iran. Although the Asmari Formation is inherently fractured, according to the distribution of boreholes and dams, and there is no case that is merely controlled by one of these elements; therefore, all factors are unequally responsible for creating a high-permeable zone. The river and adjacent karst connect in three possible ways: water flows from the river to the adjacent rock mass, the river gets water from the adjacent rock mass, and there is no hydraulic connection between the river and adjacent karst areas. The settlement of impermeable layers, such as marly limestone and marl inside carbonate bodies, may create suitable places for water collection and initiation of dissolution. Finally, at the borehole scale, it is possible to find some high-permeable zones controlled only by one of the three mentioned elements, but there is no borehole or no dam site in which all high permeable zones are controlled by only one of these elements.
\end{abstract}

\section{Introduction}

Karst is a special type of landscape developed particularly on soluble rocks such as limestone, marble, and gypsum (Ford and Williams, 1989; Stevanović, 2015) and containing caves and extensive underground water systems. Karst is often characterized by karrens, sinkholes, shafts, poljes, caves, ponors, caverns, estavelles, intermittent springs, submarine springs, lost rivers, dry river valleys, intermittently-inundated poljes, underground river systems, denuded rocky hills, karst plains, and collapses (Milanović, 2004; Parise and Gunn, 2007; Parise and Lollino, 2011). Karst conduits form the main path for water loss, and problems arise because these conduits are difficult to find. The development of karst conduits is not random within a rock mass but is a dissolution process that follows specific geological features (Wright, 1991; Palmer, 2007). Primary flow paths follow discontinuities such as joints, faults, and bedding planes (Kiraly, 1975). Water loss through the foundations and abutments of dams constructed in karstic areas leads to considerable economic costs and a loss in reservoir capacity (Milanović, 2000, 2002; Zhou and Beck, 2011; Gutierrez et al., 2014; Parise et al., 2015). The numbers of investigations related to impacts of evaporite and carbonate karst on dams (James, 1992; Romanov et al., 2003; Johnson, 2008; Milanović, 2011; Cooper and Gutierrez, 2013; Gutierrez et al., 2003, 2015) is limited. The main focus of Johnson (2008) was on gypsum karst and dam constructions in the USA. Problems associated with construction of dams and reservoirs in karstic area, and some special approaches such as grouting and geophysical investigations, have to be assumed to prevent seepage as discussed by Milanović (2011). Cooper and Gutierrez (2013) reviewed collapsing dams, violently flooding mines, tunnels, and other hazards in gypsum karstic area with some of the measures that can be considered to reduce them. Romanov et al. (2003) presented a model simulation of karstification below dams by coupling equations of dissolutional widening of fractures to hydrodynamic flow that showed increasing leakage with time. Gutierrez et al. (2003) demonstrated that one of the main causes of failure of an earth dam in the NE of Spain was subsidence by dissolution of the $4 \mathrm{~m}$ thick detrital cover with a gypsum content of about $40 \%$. Gutierrez et al. (2015) analyzed distribution of leakage paths, subsidence along the main leakage path, and origin of karst in La Loteta Dam, a reservoir built in a large karst depression developed on Tertiary evaporites. The karst features can hinder the ability of a dam to hold water in a reservoir, and can even cause collapse of a dam (Johnson, 2008). The objective of this study is to investigate the likely relationship between geology, hydraulic elements, and highly-permeable zones as water leakage paths in dam sites at borehole scale. This paper focuses on karstic dam sites in the Zagros region of Iran and used both borehole logs and hydrogeological investigations. In the Zagros, perennial high-discharge rivers originating from non-karstic watersheds traverse the karst formations and develop deep valleys. The rivers flow generally from north to south to discharge their water into the Persian Gulf at the regional base level. The dams in this study were constructed or are under construction to provide drinking water, agricultural water, and energy supplies in karstic regions (Ashjari, 2007). The main problem with these dams is water seepage from abutments or foundations.

\footnotetext{
${ }^{1}$ Geology Department, Tehran University, Iran. behnaz.shabab@modares.ac.ir

${ }^{2}$ Abanrood-Tadbir Company, Tehran, Iran. Javad_Ashjari@yahoo.com

3University of Illam, Iran. haji.karimi@gmail.com
} 


\section{Approach}

The main focus of this study is to represent the zones with high leakage potential in geological and hydrogeological perspectives. First, we need to define the terms used in this paper. Seepage or leakage zones are zones having permeability of greater than 30 Lugeon units, as considered by Houlsby (1976) in the classification of highly permeable rocks. Stratigraphy describes the overall thickness of soluble rocks (mainly limestone and dolomite) and impermeable interbeds such as shales, marl, and marly limestone. A fracture or discontinuity is any kind of joint or fault that divides the rocks into several parts. Local base level is the lowest hydraulic level of a karst aquifer that groundwater can flow through and exit as a spring or discharge to rivers without any barrier.

Karst is a network of conduits imbedded in a matrix that come together to store and transfer water underground. The presence of impermeable layers often impede water flow vertically or laterally and lead to the development of conduits or drainage horizons along bedding planes which can make seepage horizons. Therefore, it is very likely that the conduits follow bedding plane horizons completely (Fig. 1).

Discontinuities are significant with regards to seepage if they are sufficiently open to permit water to flow under a reasonable hydraulic gradient. As the pattern of conduit development is most likely controlled by large aperture fracture density and configurations, it is likely to expect that water seepage horizons follow the fracture pattern at dam sites (Fig. 2).

This paper is limited to karst areas of dam sites. Since dams are constructed over rivers with high water flow rates, the hydraulic relationship between the river and the adjacent carbonate aquifer is crucial. If the aquifer is surrounded by impermeable formations, the hydraulic connectivity of the aquifer with following aquifers is reduced, and the groundwater can flow into the river in the absence of any geological barrier (Ashjari, 2007). Therefore, rivers can act as the main local base level, which is important in understanding karst conduit development or seepage horizon (Fig. 3). Furthermore, it is possible that the river recharges the aquifer under conditions where the base level of the aquifer is not the river, the riverbed is permeable, groundwater level is lower than the river, and there is no impermeable layer between the river bed and groundwater. Over a long period of time, water infiltration around the river may lead to karst conduit development under the riverbed and between the river and groundwater level. For simplicity, the hydraulic interaction of groundwater and river as either a recharge or a discharge hydraulic factor is considered.

This case study is on different places with specific geology and hydrogeology characteristics. Borehole data were used to describe the stratigraphy of each site vertically and horizontally, with particular geological properties due to the high heterogeneity of karst. To simply compare the three major factors affecting the high-permeable horizon from borehole scale to dam

Note: These dissolution space only are related to the condition within the vadose zone.

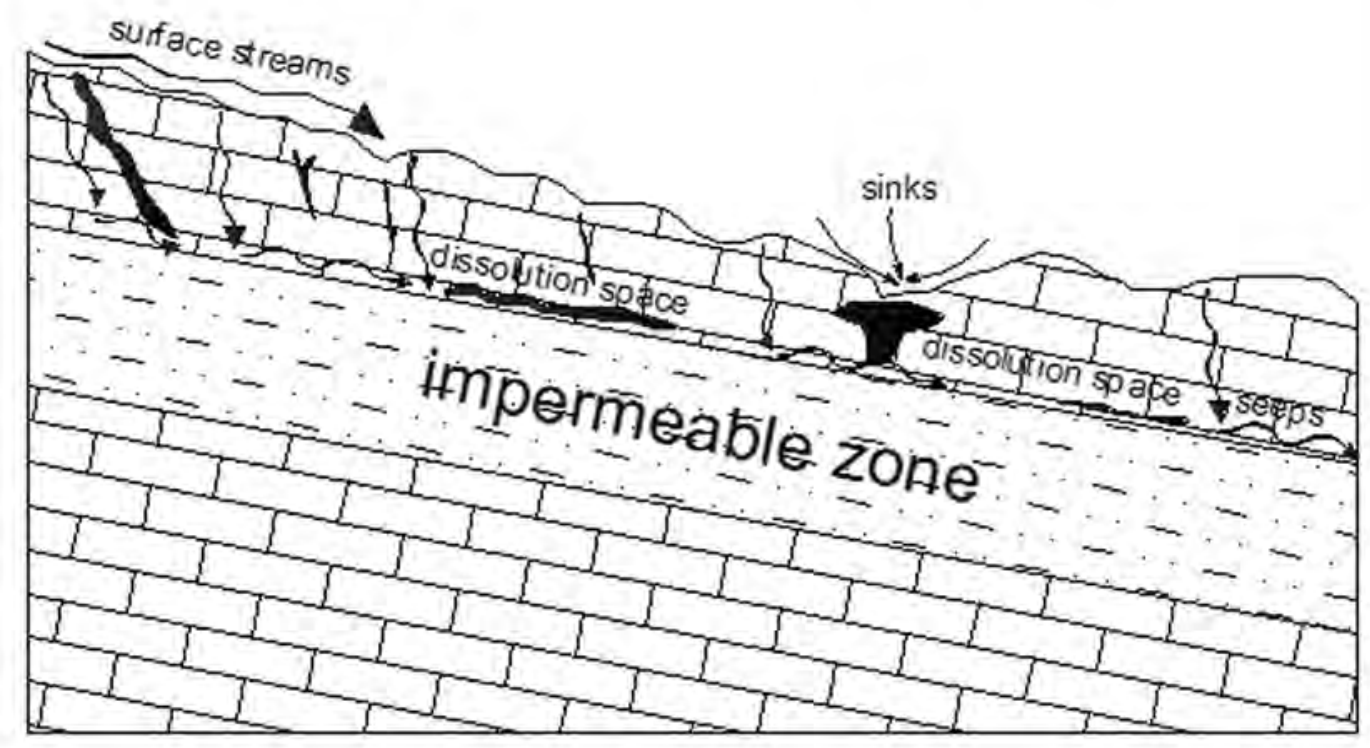

Figure 1. Role of the stratigraphy element in guiding the water flow and conduit development. site scale and regional scale, a triangular diagram was defined. It is important to mention that karst development is a complicated process that cannot be exhaustively covered by these three elements. For simplicity and to present the results, a triangular diagram with three apexes of stratigraphy, fractures, and hydraulics was assumed as shown in Figure 4. First, the diagram was drawn based on the data of boreholes for each site. Then the average of each site was determined and pre- 


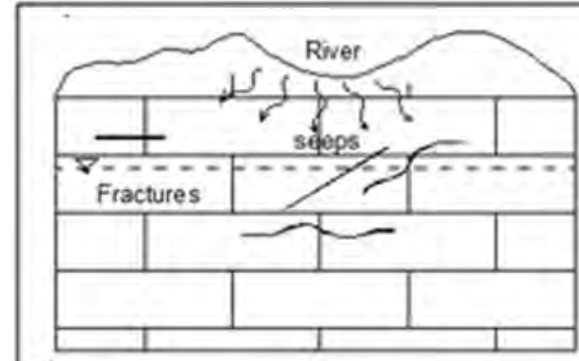

a)

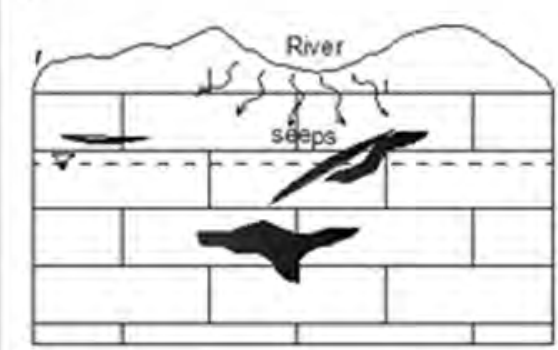

b)

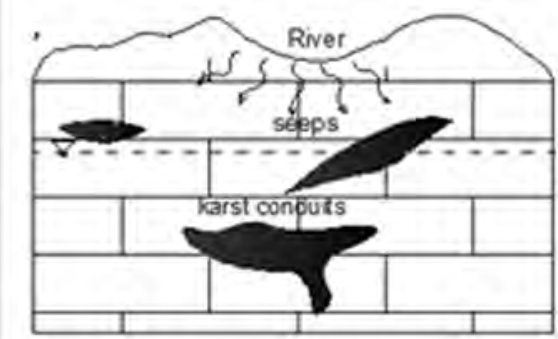

c)

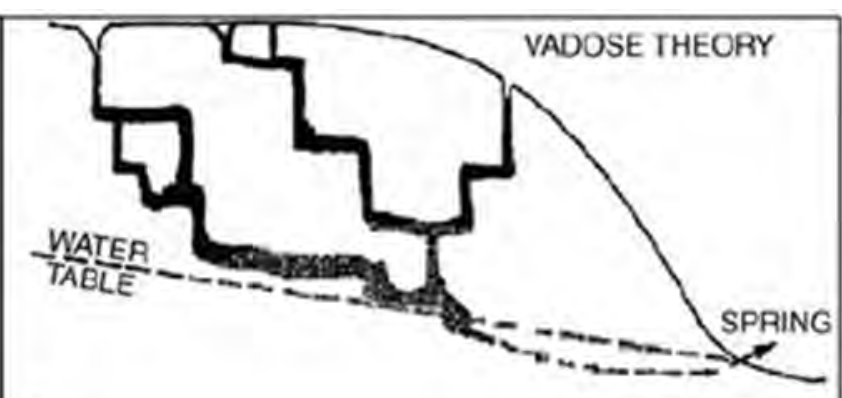

d)
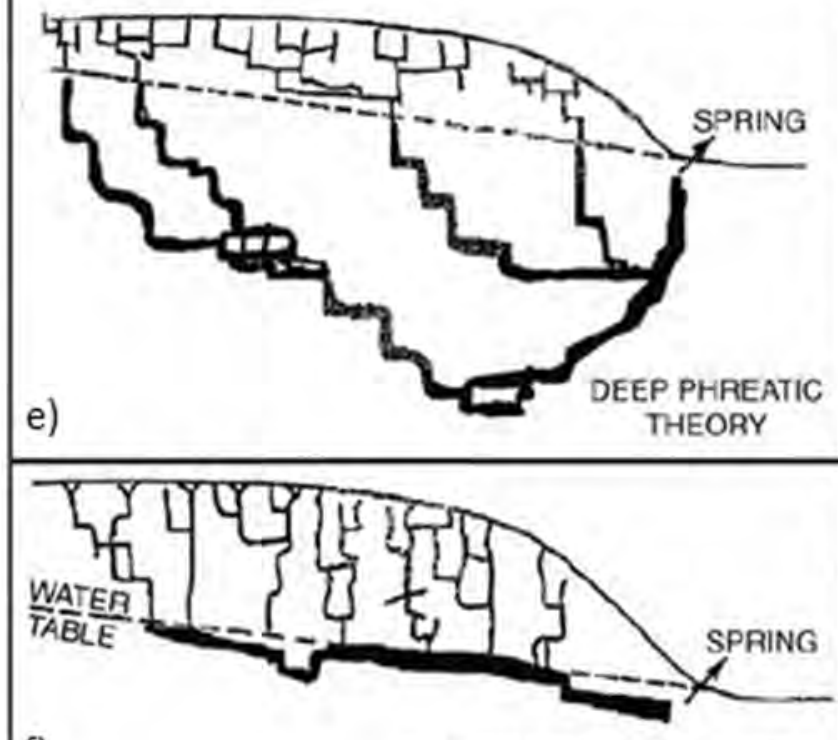

f)

\section{WATERTABLE CAVE THEORY}

Figure 2. Role of the fractures in guiding water flow and conduit developing. $A, B$, and $C$ show the steps of developing of the solution space from fractures, respectively. tains radiolarites, ophiolites, and very small amounts of basic igneous rocks of upper Cretaceous age (Falcon, 1974). The combination of halite, anhydrite, limestone, dolomite and igneous rock forms Folded Zagros. These lithological

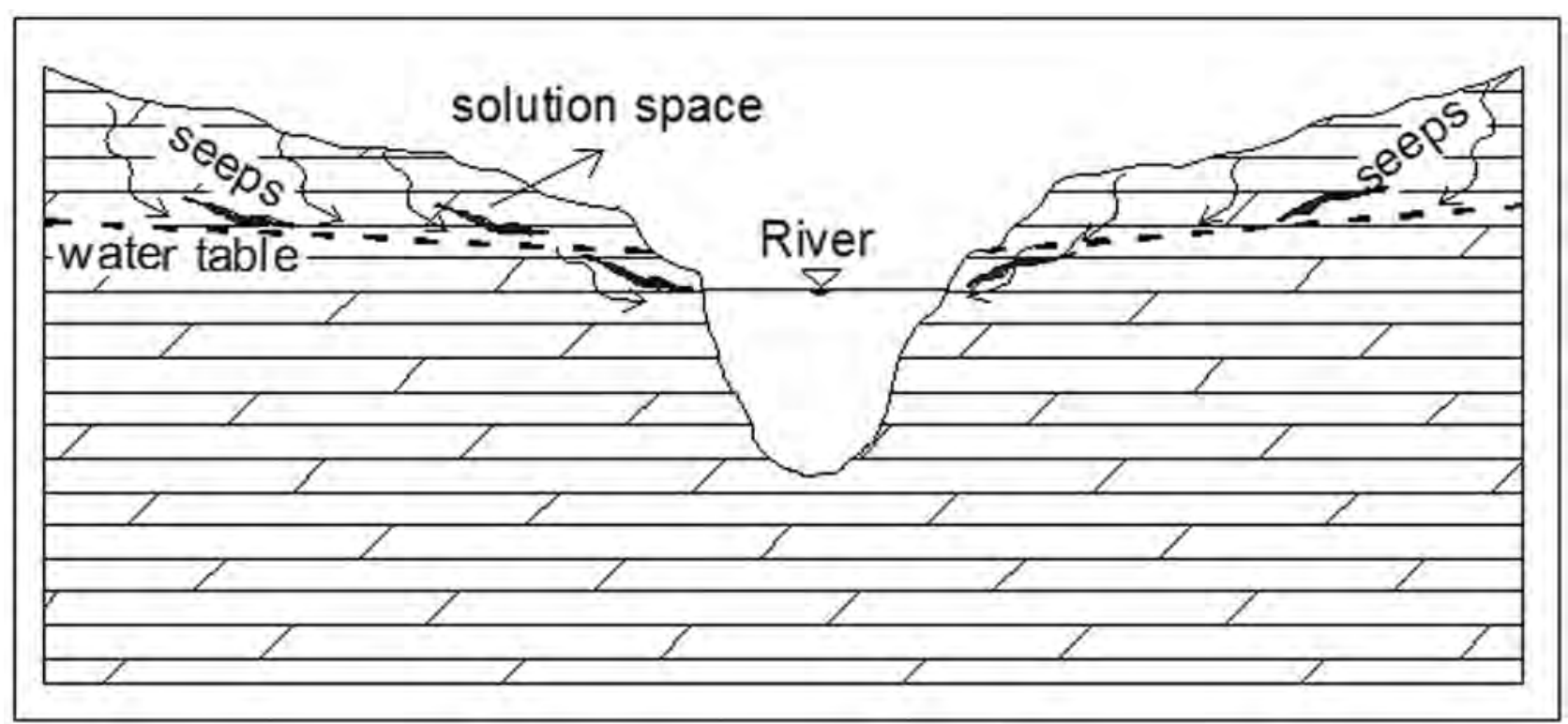

Figure 3. Role of the hydraulic element in situation of solution space. 


\section{Hydraulic}

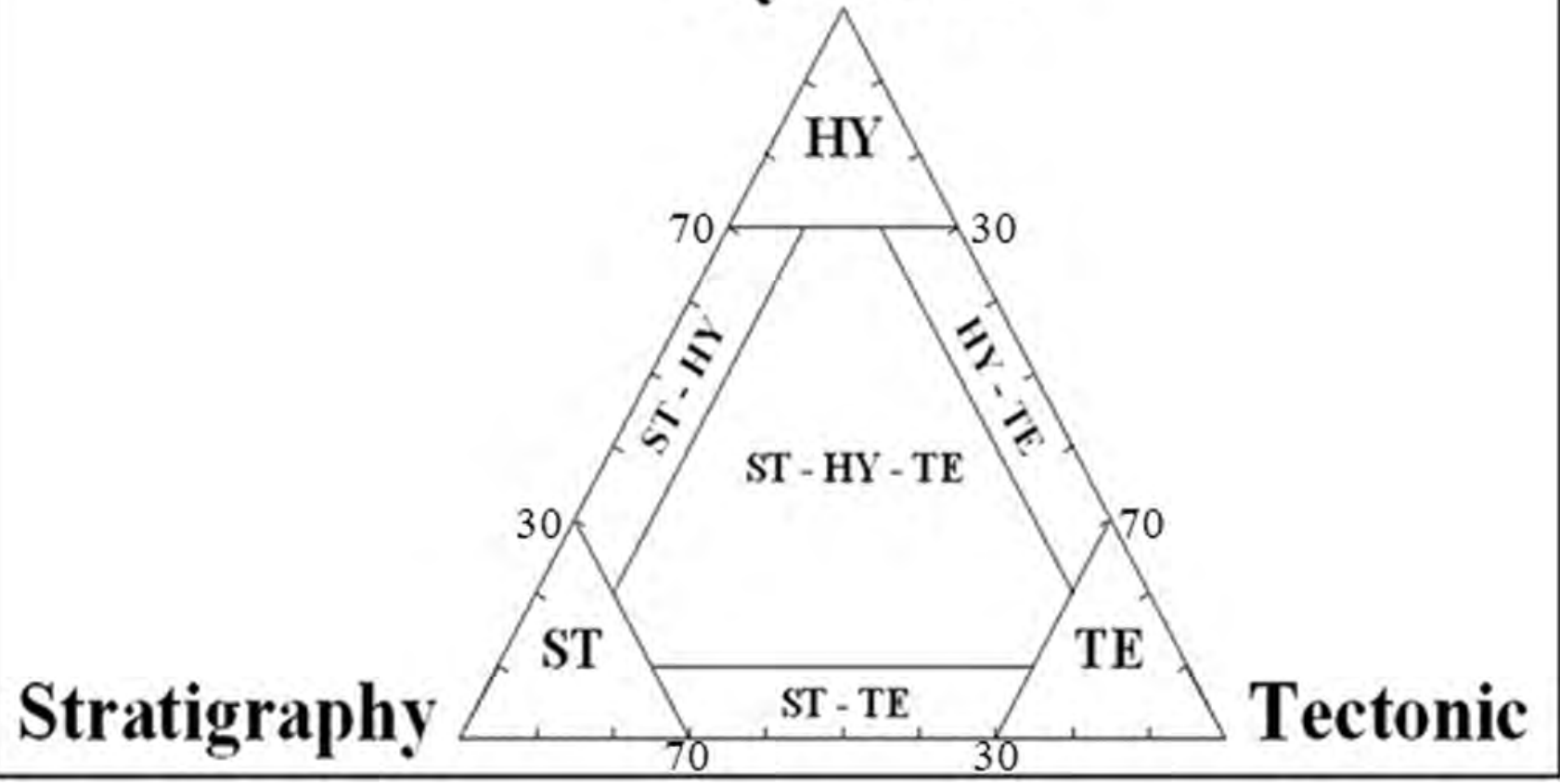

Figure 4. The assumption triangular diagram showing the role of ST, HY and TE element. (HY: Hydraulic Control range. TE: Tectonic Control range. ST: Stratigraphy Control range. ST-HY: Stratigraphy and Hydraulic Control range. HY-TE: Hydraulic and Tectonic control range. ST-TE: Stratigraphy and Tectonic control range. ST-HY-TE: Stratigraphy, Hydraulic and Tectonic Control range).

units are from upper Precambrian to middle Cambrian with 115 salt domes of late Jurassic (Aghanabati, 2004). The study areas are situated in different zones, mainly in the western parts of Zagros (Fig. 5).

The stratigraphical and structural characteristics of the Zagros sedimentary sequences have been described in detail by Stocklin and Setudehnia (1971) and Alavi (2004). In the following sections, the main outcropping formations of the study areas are discussed in decreasing order of age (Stocklin and Setudehnia, 1971; Alavi, 2004). The Gurpi, Upper Cretaceous, is composed of $350 \mathrm{~m}$ of marl, marly limestone and claystone. Pabdeh, Eocene-Paleocene, consists of $800 \mathrm{~m}$ of calcareous shale, marl, and lime mudstone with subordinate shaly limestone. Facies grade towards the southwest into the Shahbazan carbonates. The Shahbazan, Middle-Upper Eocene, is composed of $485 \mathrm{~m}$ cliff-forming dolomite interbedded with dolomitic limestone. Facies grade towards the east into the Jahrum carbonates. Eocene in age, they are composed of $485 \mathrm{~m}$ of dolomite interbedded with dolomitic limestone. The thickness of the Asmari Formation, Oligocene-Miocene, varies from a few meters up to $500 \mathrm{~m}$, consisting of medium-bedded to thick-bedded and well-jointed limestone. The

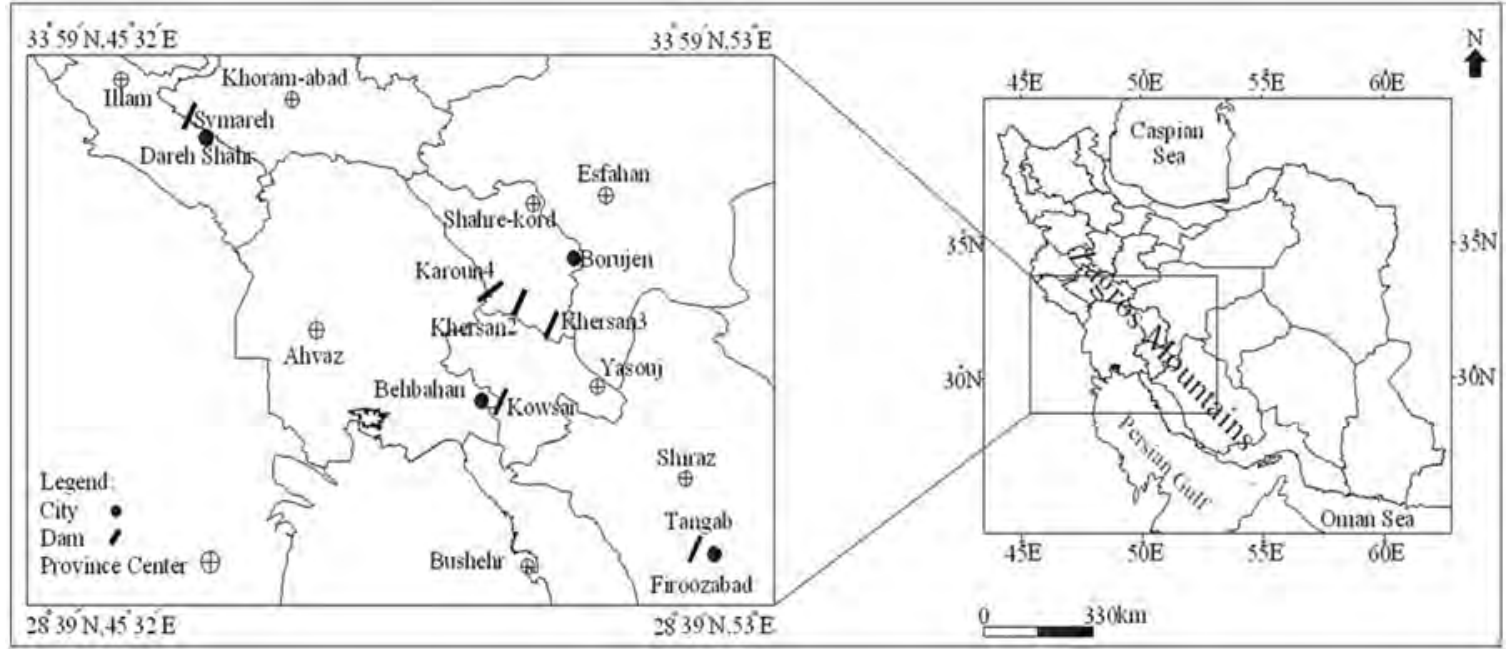

Figure 5. Location of dams in the study area, Zagros, Iran.
Gachsaran Formation, Miocene, is composed of multiple sequences of variable thicknesses (up to $1900 \mathrm{~m}$ ) and lithologies, including alternations of evaporites (gypsum, anhydrite and subordinate halite), shale, marl, and locally conglomeratic calcarenite. The Mishan Formation, 
Miocene, is composed of marl, calcareous shale, siltstone, and sandstone. The Aghajari Formation, Upper Miocene, is a thick, up to $3000 \mathrm{~m}$ succession, composed of carbonate-clast and polymict conglomerate, calcarenite, sandstone, siltstone, marl, and lime-mudstone. The younger sediments are composed mainly of conglomerate and recent alluvium (Fig. 6).

Carbonate formations control the geomorphology of the Zagros. They form cylindrical anticlines which plunge beneath younger permeable or impermeable sediments at both sides (Ashjari and Raeisi 2006). According to Ashjari and Raeisi (2006), the anticlines are bare on the top while their bottoms are bounded by impermeable layers that disconnect the hydraulic connectivity of each limb. Just in few cases, they proposed that the groundwater flow is likely to occur between two flanks at sites where the elevations of bedrocks are low enough in relation to the groundwater level of the limes. This kind of hydraulic interaction of the limbs is often detectable around the plunges or main rivers.

\section{Method of Study}

The selected dams lie in various positions in the Zagros region. Geology maps of the dam sites were prepared based on geology maps of 1/100,000 Oil Companies and Geology Surveys of Iran. The geotechnical data of drilled boreholes, such as geological logs, RQD (rock quality designation), Lugeon tests, geomorphologic data, and the size of dissolution pores and their relative location to main geological and hydraulic elements in the sites were collected. The following data and reports were gathered: flow system and hydrogeological characteristics of the sites, water level measurements in boreholes in karstic rock mass or wells, springs location and discharge, water tracing results, isotopic studies outcome, river flow rate and water level, and rainfall of the area. The main source of data was the Water Resource Management Office of Iran.

Geological logs and geotechnical data were used to find the potential horizon of conduit developments. Lugeon test results were used to find high-permeability zones in a borehole and the relation of the leakage zone to the geological characteristics of the dam sites.

From a geotechnical standpoint, permeability greater than 3 Lugeon units denotes the presence of water leakage potential, and permeability higher than 30 Lugeon units denotes a high seepage volume (Houlsby, 1976). The locations with permeability higher than 30 Lugeon units are considered the Main Seepage Zone (MSZ). The vertical variations

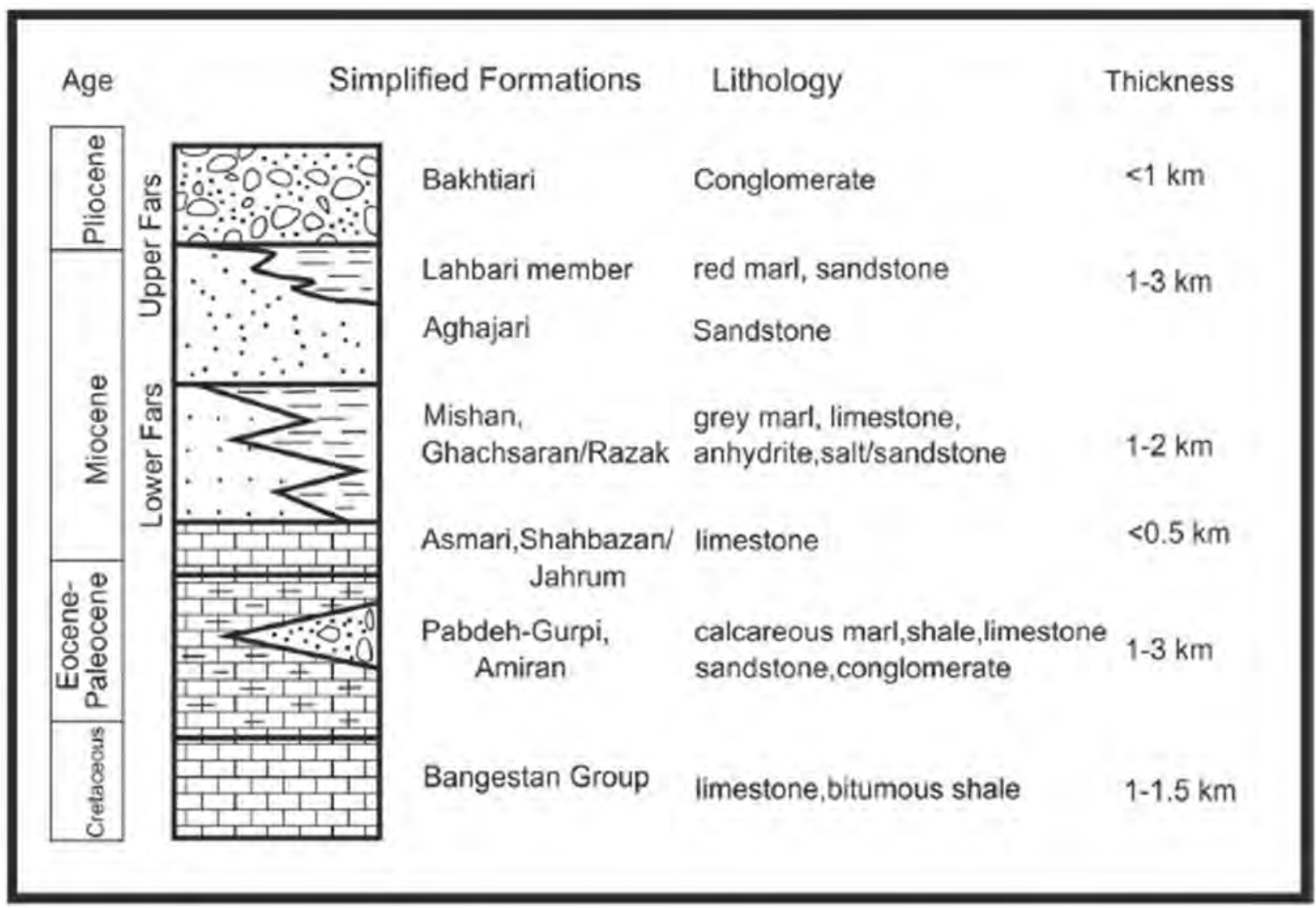

Figure 6. Simplified stratigraphy column of formations in understudy area. 
of permeability of each borehole were checked and horizons higher than 30 Lugeon units were marked as MSZ. Then, geological data of the same level of each MSZ of borehole were extracted from core logs. The presence or absence and frequency of fractures, cavity, lithology of rock within the MSZ, as well as above or below it, were determined.

The water levels of boreholes were used to find the potential hydrogeological relationship of riverbeds and aquifers or subaquifers of the dam sites, in other words, to understand if the river is the local base level of the aquifer or the river is a recharging aquifer. The method has been discussed in detail by Ashjari and Raeisi (2006). The hydrogeological results, geological investigation and geotechnical data were compiled to show the role of various elements in making water seepage horizons through dam sites at borehole scale.

A triangular diagram was used to display the results. In a ternary plot, the proportions of the three elements, fracture, stratigraphy, and hydraulic must sum up to 1.0 or $100 \%$. Every point on a diagram shows different compositions of the three variables. Based on this study, it was rarely observed that a MSZ in a specific borehole is merely controlled by one factor. Therefore, the controlling elements of each MSZ are determined. The presence or absence of each element is more important than frequency. For example, it is possible that an MSZ is located at highly fractured point, the impermeable layer of shale is detected adjacent to MSZs, and the hydraulic play a role. In such case, the weight of every element would be equal to $33.33 \%$. If only two elements play roles in the creation of MSZs, the weight of each of them would be $50 \%$. Then the length of each MSZ is measured, and the value of each element in a borehole was calculated based on the MSZ length. The next step was to draw borehole data on a ternary diagram. The apexes of diagram show the points in which each element has the weight of $100 \%$, and the sides of triangles were divided from 0 $\%$ to $100 \%$, which reduce from apex toward the facing side. The further away from the apex, the effect of the element decreases in creating MSZs. Finally, based on the calculated percentage of each element, the boreholes were plotted on the diagram. In reality, the diagram shows the prevailing controlling factor of MSZ at the scale of the dam site. To plot the data on a regional scale, the same method was used. Instead of using a weighting method for just one borehole, it is used for all boreholes together.

\section{Results}

Six dams were studied in this research. In all the cases, the abutment(s) and/or foundation of the dams are located on Asmari Formation. The study focuses on high seepage locations (more than 30 Lugeon units) that are considered to be MSZ. More detailed information is provided by Shabab-Boroujeni (2012). The controlling agents of all MSZs are determined based on the available information (Lugeon tests, RQD, geological information, etc.). The MSZs are plotted on the proposed triangular diagram for each borehole individually and resultant factors at dam site scale, separately. The results show that there are cases, at borehole scale, controlled barely by one of these elements while there are no cases merely controlled by one element at dam site scale. It should be noted that MSZs in the different boreholes are not the same, but belong to different leakage features. All cases are distributed in the intermediate part of the diagram, near the half side of the tectonic-stratigraphy line (Fig. 7). Therefore, it is not possible to classify the dams according to the prevailing

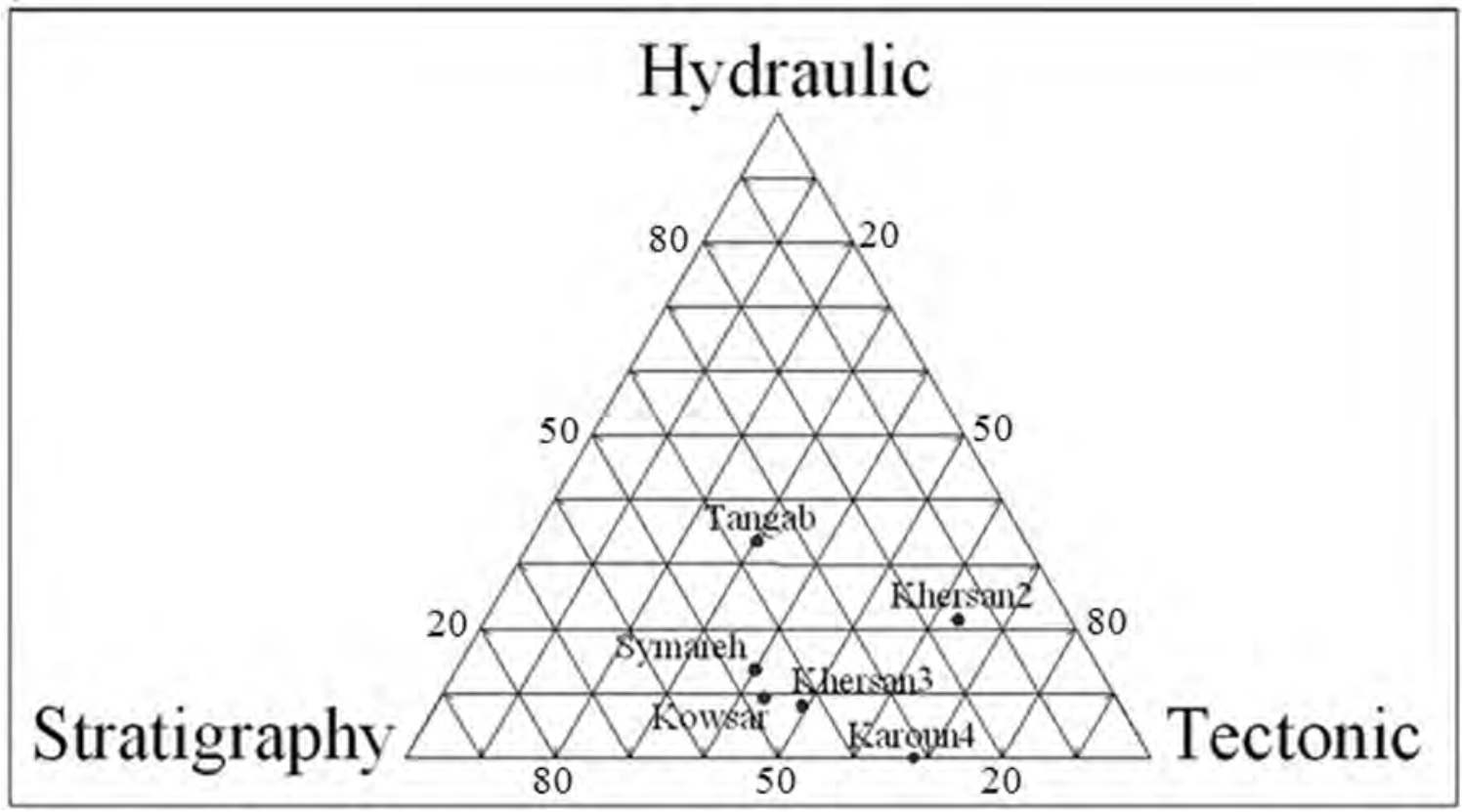

Figure 7. Diagram of classification of under study dams based on the controlling factor of MSZ. controlling factor of MSZ. To find out the role of the three elements in MSZ, three cases were selected to be discussed in more detail.

\section{Symareh Dam}

The Symareh Dam was constructed on the Symareh River, with an average discharge of 109 $\mathrm{m}^{3} \mathrm{~s}^{-1}$ and flowing perpendicular to the Ravandi Anticline axis. The anticline consists of Asmari Formation 
(well-jointed limestone) with $\sim 61 \mathrm{~km}^{2}$ exposed surface, which is the main aquifer of the area. The aquifer is surrounded by Gachsaran impervious formation (marl and gypsum) at the surface and marly layers of Pabdeh-Gurpi as bedrock. The river flows on Gachsaran and through a narrow and vertical cliff valley in the Asmari Formation (Fig. 8a). The river water level varies from 598 m.a.s.I to 610 m.a.s.I in response to precipitation, which usually occurs in the form of snow.

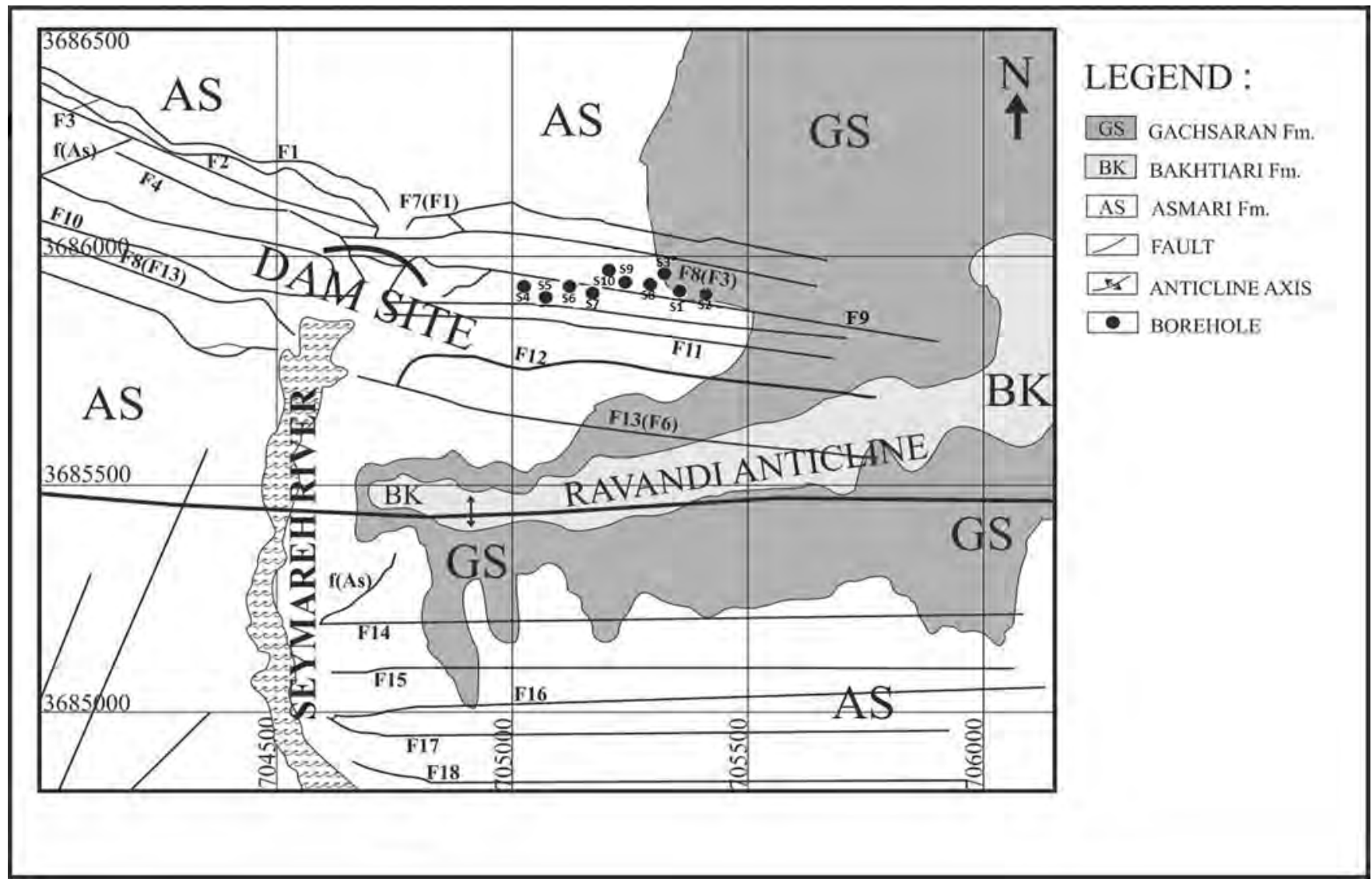

Figure 8a. Geology map of Symareh Dam Site and location of boreholes (Iran Water and Power Resources Development Co., 2008).

Hydrogeologically, karst water of Asmari's aquifer discharges only into Symareh River via 39 springs on the eastern and 2 springs on the western bank (Karimi et al., 2005). The impervious Pabdeh-Gurpi Formations (marl, shale, and marly limestone) is the bedrock of the aquifer and is located below the river level. The groundwater level fluctuates between 598 and 620 m.a.s.l, as measured in the boreholes near the river. The river acts as the local base-level of the aquifer (Ashjari and Raeisi, 2006).

Reliable data on 10 boreholes from the left abutment of Symareh Dam were obtained. The boreholes have extensive information on lithology, fracture density, cavities, Lugeon test, and RQD, with records of every $2 \mathrm{~m}$ to $5 \mathrm{~m}$. A summary of borehole data is presented in Table 1. The results show that the permeability of rocks is less than 30 Lugeon units at boreholes S1, S2, S5, and S6; however, the core logs of the boreholes show the presence of fracture and impermeable layers, or both, at different depths. Therefore, no MSZ exists. Only one point is reported to have a permeability $>30$ Lugeon at boreholes S4, S7, and S10, and more than one point at boreholes S3, S8, and S9.

Our analysis does not include locations with permeability lower than 30 Lugeon units. For clarification, boreholes S7 and S4 are located about 420 and $240 \mathrm{~m}$ to the east of the Symareh River at elevations of $642 \mathrm{~m}$.a.s.l and $637 \mathrm{~m}$.a.s.I at depths of $142 \mathrm{~m}$ and $125 \mathrm{~m}$, respectively. The results of the Lugeon test of S7 show that the permeability of different levels is $<10$ Lugeon units except at spacing of $632 \mathrm{~m}$ to $637 \mathrm{~m}$ which exhibited 85 Lugeon units. The core log analysis shows that there is a thin layer of marly limestone below the MSZ. Small cavities and fractures are also observed at that level. Examination of the differences of this level with the rest of the boreholes reveals that the frequency of fractures is very low. Although cavities were observed in other parts of the borehole, the size of cavities, at the scale of the core specimen, is bigger than the others. S4 has only one high-permeable place at the level of $611 \mathrm{~m}$ to $617 \mathrm{~m}$. The water level of the river fluctuates between 592 m.a.s.I to 612 m.a.s.l. and the groundwater level varies from $598 \mathrm{~m}$ to $620 \mathrm{~m}$ in the observed wells. No fracture was reported in that horizon, but cavities were observed. The high-permeable horizon is located in the fluctuation zone of the groundwater level. Furthermore, there is potential of water injection from river to 
Table 1. Summary of boreholes in Symareh Dam Site.

\begin{tabular}{|c|c|c|c|c|c|c|c|}
\hline $\begin{array}{l}\text { Borehole } \\
\text { Name }\end{array}$ & $\begin{array}{c}\text { Borehole } \\
\text { Level }^{a}\end{array}$ & $\begin{array}{c}\text { Number of } \\
\text { Seepage } \\
\text { Horizons }^{b}\end{array}$ & $\begin{array}{c}\text { Elevation } \\
\text { of Seepage } \\
\text { Horizons }^{\mathrm{a}}\end{array}$ & Cavity $^{c}$ & $\begin{array}{l}\text { Fractured } \\
\text { Zone }^{c}\end{array}$ & $\begin{array}{l}\text { Presence of Impurity } \\
\text { Adjacent to Horizons }\end{array}$ & $\begin{array}{c}\text { Effect of } \\
\text { Hydraulic Factor }\end{array}$ \\
\hline $\mathrm{S} 1$ & $648-708$ & 0 & - & - & - & - & - \\
\hline S2 & $653-703$ & 0 & - & - & - & - & - \\
\hline S3 & $632-682$ & 2 & $\begin{array}{l}675 \\
635\end{array}$ & $\begin{array}{l}\mathrm{N} \\
\mathrm{Y}\end{array}$ & $\begin{array}{l}Y \\
N\end{array}$ & $\begin{array}{c}\text { Mudstone } \\
\text { Marly Limestone }\end{array}$ & $\begin{array}{l}\mathrm{N} \\
\mathrm{N}\end{array}$ \\
\hline S4 & $512-637$ & 1 & 615 & Y & $\mathrm{N}$ & Stylolite Horizon & $\mathrm{N}$ \\
\hline S5 & $501-636$ & 0 & - & - & - & - & - \\
\hline S6 & $550-636$ & 0 & - & - & - & - & - \\
\hline S7 & $500-642$ & 1 & 635 & Y & $\mathrm{N}$ & Marly Limestone & $\mathrm{N}$ \\
\hline \multirow[t]{5}{*}{ S8 } & $500-639$ & 5 & 596 & Y & $\mathrm{Y}$ & Stylolite Horizon & $\mathrm{N}$ \\
\hline & & & 591 & Y & Y & Stylolite Horizon & $\mathrm{N}$ \\
\hline & & & 586 & $\mathrm{Y}$ & $\mathrm{N}$ & Stylolite Horizon & $\mathrm{N}$ \\
\hline & & & 581 & $\mathrm{Y}$ & $\mathrm{Y}$ & $\mathrm{N}$ & $\mathrm{N}$ \\
\hline & & & 571 & $\mathrm{Y}$ & $\mathrm{Y}$ & $\mathrm{N}$ & $\mathrm{N}$ \\
\hline \multirow[t]{6}{*}{ S9 } & $500-636$ & 6 & 619 & $\mathrm{Y}$ & $\mathrm{N}$ & Stylolite Horizon Stylolite & $\mathrm{N}$ \\
\hline & & & 609 & $\mathrm{Y}$ & $\mathrm{Y}$ & Horizon Stylolite Horizon & $\mathrm{N}$ \\
\hline & & & 599 & $\mathrm{Y}$ & $\mathrm{Y}$ & Stylolite Horizon & $\mathrm{N}$ \\
\hline & & & 584 & $\mathrm{Y}$ & $\mathrm{Y}$ & $\mathrm{N}$ & $\mathrm{Y}$ \\
\hline & & & 579 & $\mathrm{Y}$ & $\mathrm{N}$ & $\mathrm{N}$ & $\mathrm{Y}$ \\
\hline & & & 544 & Y & Y & & Y \\
\hline $\mathrm{S} 10$ & $500-637$ & 1 & 614 & Y & $\mathrm{Y}$ & Stylolite Horizon & $\mathrm{Y}$ \\
\hline
\end{tabular}

rocks during high flood time. Therefore, it is possible that the hydraulic element plays a crucial role in the development of low-level permeable zone of S4, whereas it is not important for the high-permeable zone of S7. The high-permeable zone of S7 is located beneath a thin layer of the Gachsaran Formation, gypsum and marl. The aggressive precipitation water infiltrates from Gachsaran layer to carbonate formation. The marly limestone interbed impedes the vertical movement of groundwater locally, and allows the water to dissolve carbonate and create the high-permeable zone. Consequently, the presence of the impermeable layer is crucial in the formation of high-permeable zone.

The same analysis was performed for all the boreholes. The MSZs of borehole S3 (2 zones) were limited by marly limestone and mudstone as interbedded inside the Asmari limestone body. Stylolite is common in limestones and is generally marked by insoluble constituents such as clay minerals and pyrite. It is reported to be present in the lithology column of boreholes S4, S8, S9, and S10 at various levels adjacent to high-permeable locations. It seems that this kind of impermeable thin layers may cause the formation of seepage zones.

Six horizons were scattered at the same level of the river and the groundwater level fluctuation zone. It is expected that the presence of MSZs is not extended to elevations lower than the river stage because the river acts as the local base level of the area, so that the possibility of dam-induced karstification is limited and controlled by the river elevation. However, there are three points with MSZ at borehole S9 which are located deeper than the river level at about 10 $\mathrm{m}$ to $50 \mathrm{~m}$. Cavities and rod falls were reported in 15 out of the $16 \mathrm{MSZs}$. These horizons have the highest frequency of fracture, which is sufficient to create a high-permeable zone. These zones could be connected to surface water by interconnected networks of fractures and permit water seepage. A schematic cross section of high-permeable zones is presented in Figure 8b.

\section{Tangab Dam}

The Tangab Dam, with a reservoir capacity of $90 \mathrm{Mm}^{3}$, was constructed over the Firozabad River, $90 \mathrm{~km}$ south of Shiraz. The Firozabad River water level varies from 1390 m.a.s.I to 1400 m.a.s.l, flows through the U-shaped Tangab Valley located in the catchment area of Qomp spring. The spring emerges from the central section of the Podenow anticline, which consists of the Asmari Formation (well-jointed limestone) as the main aquifer (Fig 9a). The carbonate formation is surrounded by younger transitional layers of marl and marly limestone and older marly layers of Pabdeh-Gurpi as bedrock. Two dye tests were injected into two boreholes on the left and right abutment of Tangab Dam and they appeared in Qomp spring (Ashjari 2007). The groundwater levels are about $20 \mathrm{~m}$ to $27 \mathrm{~m}$ below the river at the dam site. The water budget studies by Karimi et al. (2005) shows that the Firozabad River recharges Qomp's spring catchment area about $100 \mathrm{~L} \mathrm{~s}^{-1}$. Ashjari (2007) demonstrated that the main local base level of aquifers is Qomp Spring. He further reported that the Firozabad River is not the local base level of aquifers in its entrance section to the Tangab Valley in the north, but rather it turns into the local base level of the area after exiting the valley south of the aquifer (Ashjari, 2007). 


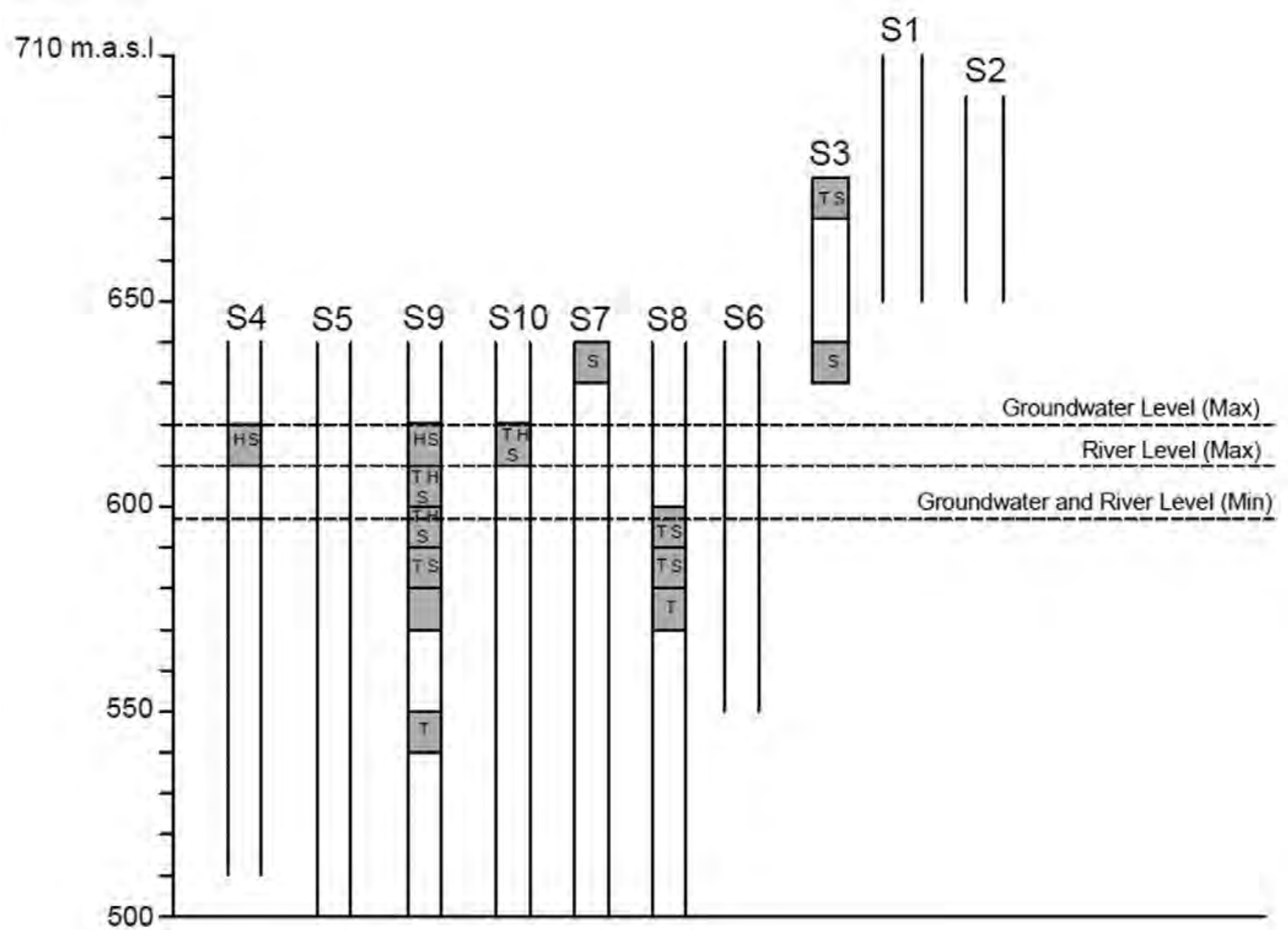

Figure 8b. Fluctuation of groundwater level and river level at boreholes in Symareh Dam Site.

Thirteen boreholes at both abutments of Tangab Dam were studied (Table 2). Fig. 9b shows a schematic cross section of boreholes, groundwater, and river levels. No MSZ was detected in the three boreholes that were drilled more than $70 \mathrm{~m}$ away from the river. Eighteen MSZs were found in both abutments of the dam, distributed unevenly from elevations of 1300 m.a.s.I to 1447 m.a.s.I. Fractures and an impermeable thin layer, represented by marly limestone, were observed in 14 cases. Borehole T1 is located $5 \mathrm{~m}$ away from the river, and is the only case without evidence of fractures or an impermeable layer. Four horizons are located in the same level of the river; six horizons are in the space between the river level and groundwater levels; four are detected in the groundwater level fluctuation zone, four horizons are deeper than the water table, and only one horizon is higher than the river.

The deepest horizon, located in borehole $T 7$, is about $50 \mathrm{~m}$ below the groundwater level, which is limited by marl limestones at the bottom, while no fracture zone was present nearby. Borehole T7 had another horizon about $10 \mathrm{~m}$ below the groundwater level but it is a fractured zone without evidence of an impermeable layer below or above the zone. The remaining deep seated MSZs, at boreholes T12 and T6, are fractured and imbedded by marly limestone. In addition to the deep horizons, in the boreholes drilled very close to the river (less than $10 \mathrm{~m}$ ), there are one or two horizons with high-seepage at groundwater level or in the space between the river and groundwater. The highest MSZ lies about $5 \mathrm{~m}$ above the maximum river stage ( $70 \mathrm{~m}$ away from the river) in a fractured zone next to marly limestone. There is a fairly good relationship between the MSZ depth and distance from the river. The boreholes close to the river have higher permeability, which implies that existence of some passages in depth is more likely.

Although a karst conduit is seldom reported in boreholes logs, there are three exposed caves close to the dam site, and during excavation of the dam's galleries, one hidden shaft was exposed.

\section{Kowsar Dam}

Kowsar Dam, with a capacity of $570 \mathrm{Mm}^{3}$, was constructed on Khirabad River in the Douk anticline to supply the demand for water of two provinces in south Iran. Geologically, the dam abutments and foundation are based on carbonate layers which are covered by gypsum and cemented conglomerate, and recent alluvial sediments (Fig. 10a). The layers 


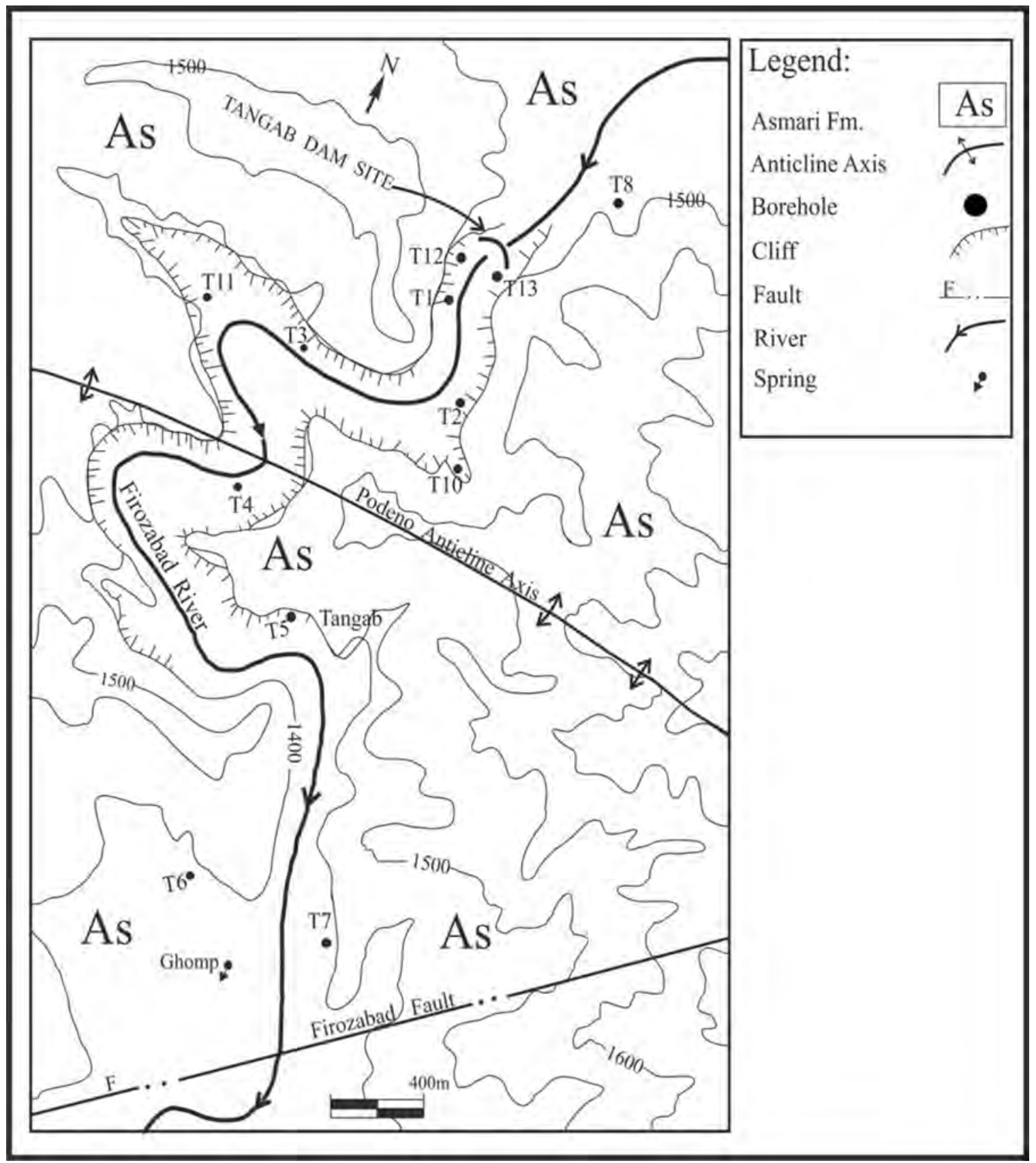

Figure 9a. Geology map of Tangab Dam Site and boreholes (Nadri, 1999). are approximately horizontal, dipping less than $6^{\circ}$ around the dam. The lowest elevation of the exposed part of Asmari (well-jointed limestone), as the main aquifer in the area, is in the southern plunge of the anticline.

$\mathrm{H}$ ydrogeologically, Pabdeh-Gurpi (marl, shale, and marly limestone) as bedrock does not inhibit the hydrogeological relationship of both flanks of the anticline. Although the river has incised the Asmari Formation (well-jointed limestone), at least at the dam site, there is no hydraulic relationship between the river and the aquifer, which has been confirmed by dye test and isotopic analysis (Water Research Centre of Iran, 1997). The general direction of groundwater

flow is towards the southern plunge of the anticline (Rahanjam, 2009). The borehole study reports the presence of 56 MSZs at 8 boreholes distributed at different levels: 45 at higher elevation than the river, 2 MSZs at the groundwater level fluctuation zone, and 7 below groundwater level (Table 3). The space between the river's bedrock and the groundwater level is too thin to hold any horizon inside it and the absence of hydraulic connectivity between the river and the aquifer results in a non-seepage zone.

A schematic cross section of high-permeable zones is presented in Figure 10b. The impermeable layers, here consisting of marls and marly limestones, were adjacent to 32 out of 56 MSZs ( 57\%), and 28 horizons are in fractured zones. Neither fractured zones nor impermeable layers were observed in 12 horizons distributed in different levels. The three deepest horizons lie $15 \mathrm{~m}$ to $20 \mathrm{~m}$ below the river level which is limited by marly limestones, with one horizon fractured.

Cavities of different sizes are reported inside 39 horizons. In three horizons, no cavity, impermeable layer or fracture was observed. Therefore, it is possible to find a MSZ without any evidence of primary elements of karst development. The cause of MSZ can be removed by excessive development of one passage which erodes the impermeable layers, or when several minor passages combine into one passage. 
Table 2. Summary of boreholes in Tangab Dam Site.

\begin{tabular}{|c|c|c|c|c|c|c|c|}
\hline $\begin{array}{l}\text { Borehole } \\
\text { Name }\end{array}$ & $\begin{array}{l}\text { Borehole } \\
\text { Level }^{\mathrm{a}}\end{array}$ & $\begin{array}{l}\text { Number of } \\
\text { Seepage } \\
\text { Horizons }^{b}\end{array}$ & $\begin{array}{l}\text { Elevation } \\
\text { of Seepage } \\
\text { Horizons }^{\mathrm{a}}\end{array}$ & Cavityc & $\begin{array}{l}\text { Fractured } \\
\text { Zone }^{c}\end{array}$ & $\begin{array}{l}\text { Presence of Impurity } \\
\text { Adjacent to Horizons }\end{array}$ & $\begin{array}{l}\text { Effect of } \\
\text { Hydraulic } \\
\text { Factor }\end{array}$ \\
\hline $\mathrm{T} 1$ & $1360-1405$ & 2 & $\begin{array}{l}1390 \\
1365\end{array}$ & $\begin{array}{l}\mathrm{N} \\
\mathrm{N}\end{array}$ & $\begin{array}{l}\mathrm{Y} \\
\mathrm{N}\end{array}$ & $\begin{array}{l}\text { Marly Limestone } \\
\mathrm{N}\end{array}$ & $\begin{array}{l}Y \\
Y\end{array}$ \\
\hline $\mathrm{T} 2$ & $1360-1406$ & 1 & 1399 & $\mathrm{~N}$ & $\mathrm{~N}$ & Marly Limestone & $\mathrm{Y}$ \\
\hline T3 & $1360-1394$ & 2 & $\begin{array}{l}1384 \\
1367\end{array}$ & $\begin{array}{l}\mathrm{N} \\
\mathrm{N}\end{array}$ & $\begin{array}{l}Y \\
Y\end{array}$ & $\begin{array}{l}\mathrm{N} \\
\mathrm{N}\end{array}$ & $\begin{array}{l}Y \\
Y\end{array}$ \\
\hline $\mathrm{T} 4$ & $1357-1397$ & 2 & $\begin{array}{l}1382 \\
1367\end{array}$ & $\stackrel{N}{N}$ & $\begin{array}{l}\mathrm{N} \\
\mathrm{N}\end{array}$ & $\begin{array}{l}\text { Marly Limestone } \\
\text { Marly Limestone }\end{array}$ & $\begin{array}{l}Y \\
Y\end{array}$ \\
\hline T5 & $1330-1364$ & 0 & - & - & - & - & - \\
\hline T6 & $1325-1387$ & 2 & $\begin{array}{l}1345 \\
1314\end{array}$ & $\begin{array}{l}\mathrm{N} \\
\mathrm{N}\end{array}$ & $\begin{array}{l}Y \\
Y\end{array}$ & $\begin{array}{l}\text { Marly Limestone } \\
\text { Marly Limestone }\end{array}$ & $\stackrel{N}{N}$ \\
\hline $\mathrm{T} 7$ & $1299-1369$ & 3 & $\begin{array}{l}1356 \\
1339 \\
1305\end{array}$ & $\begin{array}{l}\mathrm{N} \\
\mathrm{Y} \\
\mathrm{N}\end{array}$ & $\begin{array}{l}Y \\
Y \\
N\end{array}$ & $\begin{array}{l}\text { Marly Limestone } \\
\mathrm{N} \\
\text { Marly Limestone }\end{array}$ & $\begin{array}{l}Y \\
Y \\
N\end{array}$ \\
\hline T8 & $1327-1447$ & 0 & - & - & - & - & - \\
\hline T9 & $1292-1442$ & 0 & - & - & - & - & - \\
\hline $\mathrm{T} 10$ & $1300-1430$ & 1 & 1417 & $\mathrm{~N}$ & $\mathrm{Y}$ & Marly Limestone & $\mathrm{N}$ \\
\hline $\mathrm{T} 11$ & $1263-1393$ & 1 & 1378 & $\mathrm{~N}$ & $\mathrm{Y}$ & Marly Limestone & $\mathrm{Y}$ \\
\hline $\mathrm{T} 12$ & $1275-1425$ & 3 & $\begin{array}{l}1391 \\
1376 \\
1336\end{array}$ & $\begin{array}{l}\mathrm{Y} \\
\mathrm{N} \\
\mathrm{N}\end{array}$ & $\begin{array}{l}Y \\
Y \\
Y\end{array}$ & $\begin{array}{l}\text { Marly Limestone } \\
\text { Marly Limestone } \\
\text { Marly Limestone }\end{array}$ & $\begin{array}{l}Y \\
Y \\
N\end{array}$ \\
\hline T13 & $1295-1425$ & 1 & 1395 & $\mathrm{~N}$ & $\mathrm{Y}$ & Marly Limestone & $\mathrm{Y}$ \\
\hline
\end{tabular}

a The elevations are reported as a.m.s.I.

${ }^{\mathrm{b}}$ Number of horizon with permeability more than 30 Lugeon units.

${ }^{c} \mathrm{Y}$ : means presence, and $\mathrm{N}$ : means absent.

Note: Tangab River Level = 1390-1400 m.a.s.l; Groundwater Level $=$ variable.

\section{Discussion}

The presence of impermeable layers such as marl, marly limestone, and clay within a permeable section can guide the flow of water along the contact of the impermeable layer and karstifiable rocks (Fig. 1). Subsequently, the dissolution of carbonate rocks can lead to development of karst conduits as main seepage horizons. These horizons are concordant with the inception horizon hypothesis by Lowe (1992). It is noteworthy that this concept was proposed by Ford and Ewers (1978), White (1988), Ford and Williams (1989) and Palmer (1975 and 1991) without using the term "inception

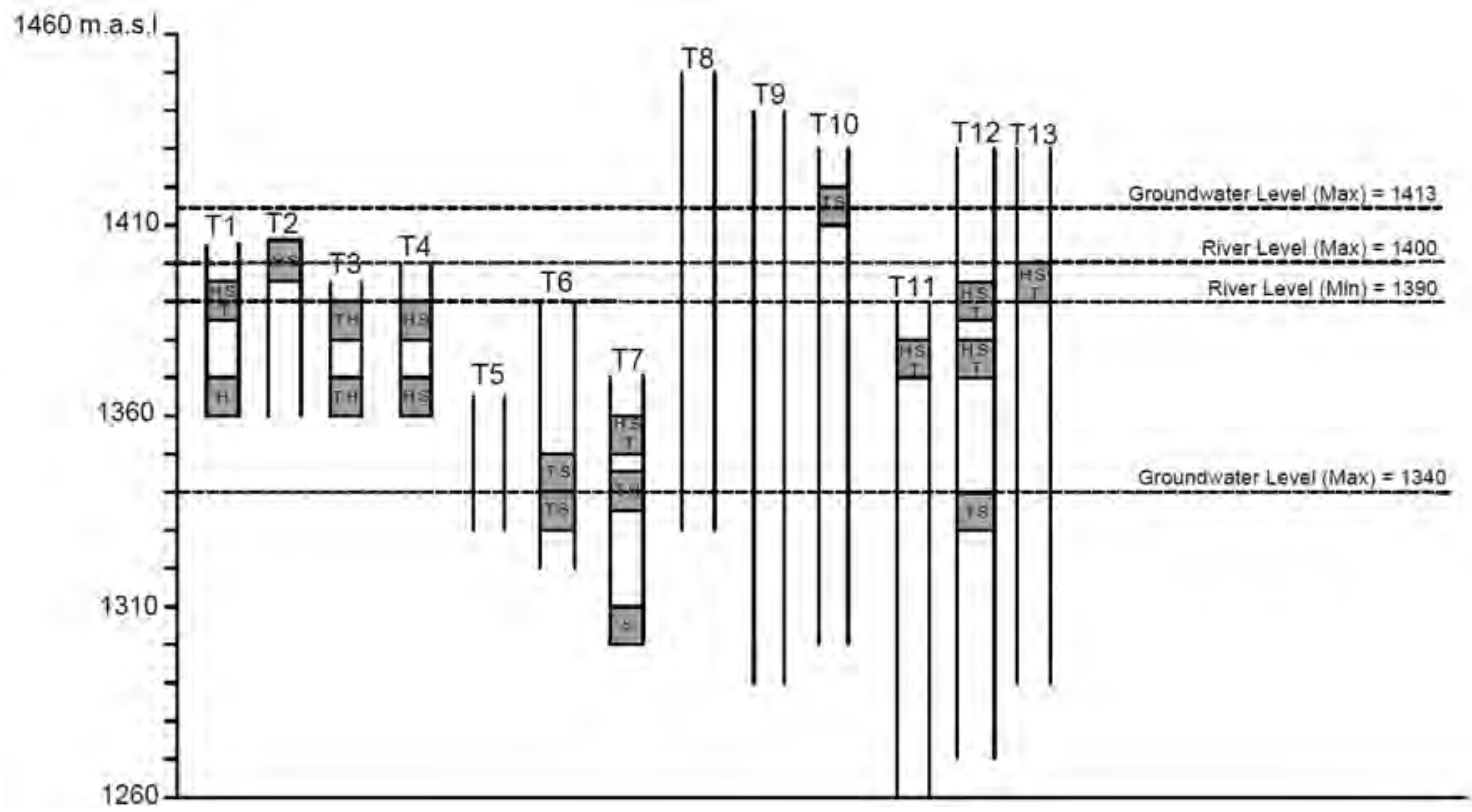

Figure 9b. Fluctuation of groundwater level and river level at boreholes in Tangab Dam Site. horizon".

It seems the role of an inception horizon is not too important among the selected dams to plot close to the stratigraphic apex of the triangular diagram (Fig. 7). However, there is only one out of 30 boreholes which absolutely matches this apex. It could be due to two possible factors: a) it is possible that the inception horizons fully control the karst 


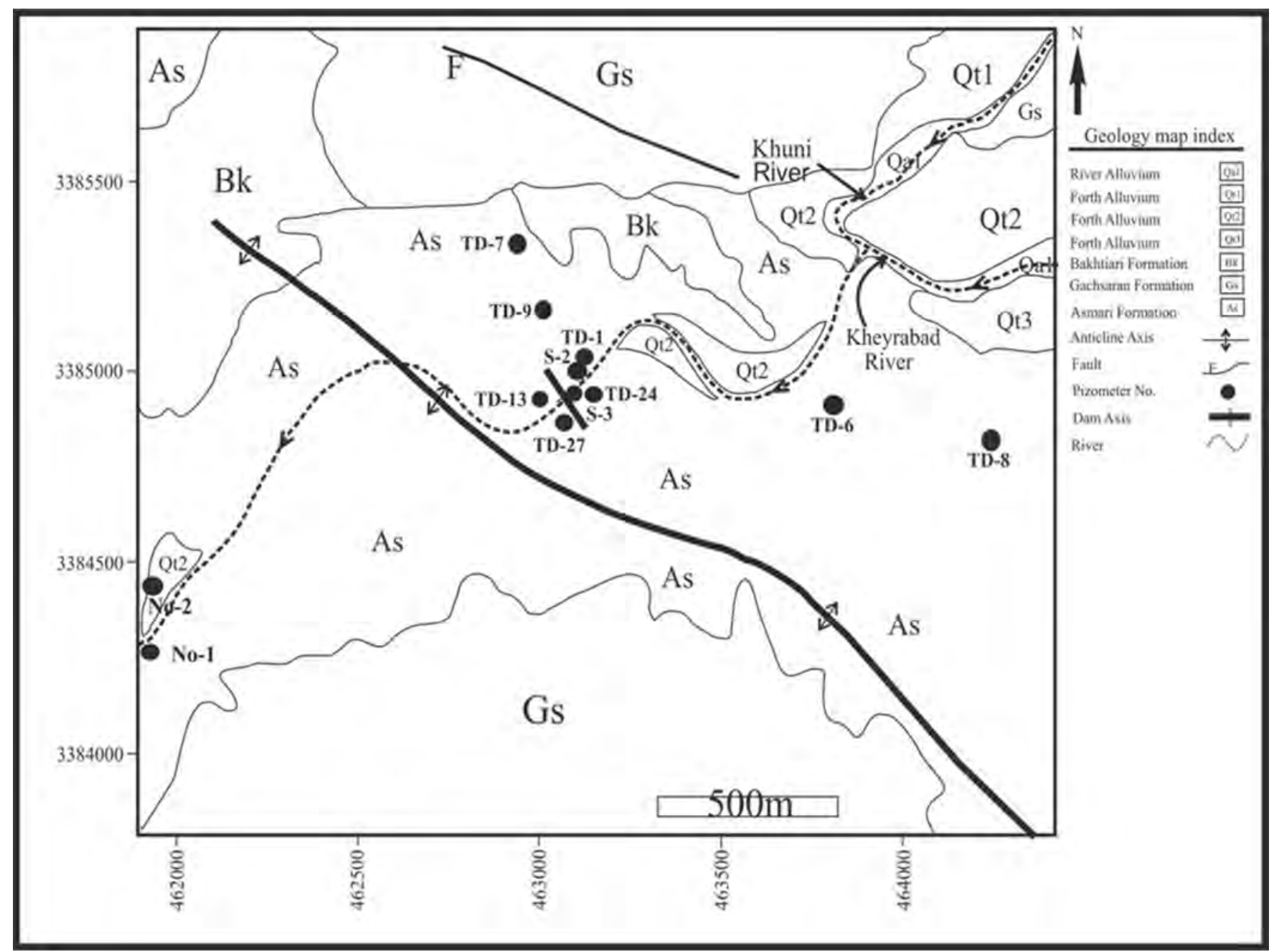

Figure 10a. Geology map of Kowsar Dam Site and boreholes.

conduit development at a zone, but it cannot be the main factor in larger areas such as dam sites or regional scales. It appears that the inception zone is randomly developed by geological elements or our knowledge is not adequate to report a general role for karst development based on inception horizons. Alternatively, the current evidence of ancient inception horizons disappeared due to geological alterations since the formation of these zones or the paleohydraulic history of the region erodes this evidence.

The presence of fractures and impermeable layers in some horizons permits the formation of intensively-developed passages with high-permeability to transfer water. The impermeable layers retard the easy water movement inside the carbonate rocks but this diverts the water to a fracture that connects the two karstic layers. The hydraulic concentration of water in such fractures allows high volumes of water to enter the fractured carbonate rocks; therefore, the passages develop into MSZ.

The role of rivers and their location relative to soluble layers is crucial in making a MSZ. If a river discharges the carbonate rock as an aquifer, such as the Symareh Dam site, the MSZs are most likely to be distributed at the same level of the river, and groundwater level is controlled by the river as well. In such conditions, the probability of MSZ presence in levels higher or lower than the river stage and groundwater table fluctuation zone will decrease. Although the fractures and impermeable layer in the same level of rivers can aggregate the karst conduit development, they are likely to be washed away by water flow. The horizontal extension of MSZ can be very far from the river banks, but it is vertically limited to the river level. For such a situation, the area must be tectonically stable to some extent for a significant geological time. If the region is active, the river will incise the karstic layer faster and the developed karst conduits will be limited to the valley walls as thin and shallow karstic zones.

At Tangab Dam, the river recharges the aquifer because the river is not at the base level of the surrounding karstic aquifer. The high volumes of water seeping from the river's bed are guided by fractures and voids to reach the ground- 
Table 3. Summary of boreholes in Kowsar Dam Site.

\begin{tabular}{|c|c|c|c|c|c|c|c|}
\hline $\begin{array}{l}\text { Borehole } \\
\text { Name }\end{array}$ & $\begin{array}{c}\text { Borehole } \\
\text { Level }^{\mathrm{a}}\end{array}$ & $\begin{array}{c}\text { Number of } \\
\text { Seepage Horizons }\end{array}$ & $\begin{array}{c}\text { Elevation of } \\
\text { Seepage Horizons }\end{array}$ & Cavity $^{c}$ & $\begin{array}{c}\text { Fractured } \\
\text { Zone }^{c}\end{array}$ & $\begin{array}{l}\text { Presence of } \\
\text { Impurity } \\
\text { Adjacent to } \\
\text { Horizons }\end{array}$ & $\begin{array}{l}\text { Effect of } \\
\text { Hydraulic } \\
\text { Factor }\end{array}$ \\
\hline $\mathrm{K} 1$ & $489-579$ & 5 & $\begin{array}{l}568 \\
556 \\
553 \\
550 \\
535\end{array}$ & $\begin{array}{l}Y \\
N \\
Y \\
Y \\
N\end{array}$ & $\begin{array}{l}Y \\
Y \\
N \\
N \\
N\end{array}$ & $\begin{array}{l}N \\
N \\
N \\
N \\
N\end{array}$ & $\begin{array}{l}\mathrm{N} \\
\mathrm{N} \\
\mathrm{N} \\
\mathrm{N} \\
\mathrm{N}\end{array}$ \\
\hline $\mathrm{K} 2$ & $456-610$ & 6 & $\begin{array}{l}602 \\
567 \\
562 \\
547 \\
542 \\
532\end{array}$ & $\begin{array}{l}\mathrm{Y} \\
\mathrm{N} \\
\mathrm{Y} \\
\mathrm{Y} \\
\mathrm{Y} \\
\mathrm{Y}\end{array}$ & $\begin{array}{l}N \\
Y \\
N \\
N \\
Y \\
N\end{array}$ & $\begin{array}{c}\text { Marly Limestone } \\
\mathrm{N} \\
\mathrm{N} \\
\mathrm{N} \\
\mathrm{N} \\
\mathrm{N}\end{array}$ & $\begin{array}{l}N \\
N \\
N \\
N \\
N \\
N\end{array}$ \\
\hline K3 & $538-618$ & 9 & $\begin{array}{l}605 \\
595 \\
590 \\
585 \\
580 \\
575 \\
560 \\
555 \\
550\end{array}$ & $\begin{array}{l}N \\
Y \\
Y \\
Y \\
N \\
N \\
Y \\
Y \\
N\end{array}$ & $\begin{array}{l}Y \\
N \\
Y \\
Y \\
Y \\
N \\
N \\
Y \\
N\end{array}$ & $\begin{array}{c}\mathrm{N} \\
\text { Marly Limestone } \\
\mathrm{N} \\
\mathrm{N} \\
\mathrm{N} \\
\mathrm{N} \\
\mathrm{N} \\
\mathrm{N} \\
\mathrm{N}\end{array}$ & $\begin{array}{l}N \\
N \\
N \\
N \\
N \\
N \\
N \\
N \\
N\end{array}$ \\
\hline K4 & $477-617$ & 4 & $\begin{array}{l}604 \\
599 \\
589 \\
584\end{array}$ & $\begin{array}{l}\mathrm{Y} \\
\mathrm{Y} \\
\mathrm{N} \\
\mathrm{Y}\end{array}$ & $\begin{array}{l}N \\
N \\
Y \\
N\end{array}$ & $\begin{array}{c}\text { Marly Limestone } \\
\text { Marly Limestone } \\
\mathrm{N} \\
\mathrm{N}\end{array}$ & $\begin{array}{l}N \\
N \\
N \\
N\end{array}$ \\
\hline K5 & $483-608$ & 3 & $\begin{array}{l}530 \\
520 \\
505\end{array}$ & $\begin{array}{l}Y \\
Y \\
Y\end{array}$ & $\begin{array}{l}\mathrm{N} \\
\mathrm{N} \\
\mathrm{N}\end{array}$ & $\begin{array}{c}\text { Marly Limestone } \\
\mathrm{N} \\
\mathrm{N}\end{array}$ & $\begin{array}{l}N \\
N \\
Y\end{array}$ \\
\hline K6 & $491-606$ & 16 & $\begin{array}{l}598 \\
593 \\
588 \\
583 \\
573 \\
568 \\
553 \\
548 \\
543 \\
538 \\
533 \\
528 \\
513 \\
508 \\
498 \\
493\end{array}$ & $\begin{array}{l}Y \\
Y \\
Y \\
Y \\
N \\
Y \\
Y \\
Y \\
Y \\
N \\
Y \\
N \\
Y \\
Y \\
Y \\
N\end{array}$ & $\begin{array}{l}Y \\
N \\
Y \\
N \\
Y \\
N \\
Y \\
N \\
Y \\
Y \\
Y \\
N \\
Y \\
Y \\
Y \\
Y\end{array}$ & $\begin{array}{c}\text { Marly Limestone } \\
\text { Marly Limestone } \\
\mathrm{N} \\
\text { Marly Limestone } \\
\text { Marly Limestone } \\
\text { Marly Limestone } \\
\text { Marly Limestone } \\
\mathrm{N} \\
\text { Marl } \\
\text { Marl } \\
\text { Marl } \\
\text { Marly Limestone } \\
\text { Marl } \\
\text { Marl } \\
\text { Marl } \\
\text { Marl }\end{array}$ & $\begin{array}{l}N \\
N \\
N \\
N \\
N \\
N \\
N \\
N \\
N \\
N \\
N \\
N \\
N \\
Y \\
Y \\
N\end{array}$ \\
\hline K7 & $480-510$ & 2 & $\begin{array}{l}492 \\
487\end{array}$ & $\begin{array}{l}\mathrm{Y} \\
\mathrm{N}\end{array}$ & $\begin{array}{l}Y \\
Y\end{array}$ & $\begin{array}{l}\text { Marly Limestone } \\
\text { Marly Limestone }\end{array}$ & $\begin{array}{l}\mathrm{N} \\
\mathrm{N}\end{array}$ \\
\hline K8 & $458-558$ & 11 & $\begin{array}{l}550 \\
545 \\
535 \\
530 \\
515 \\
510 \\
505 \\
500 \\
490 \\
485 \\
480\end{array}$ & $\begin{array}{l}Y \\
Y \\
N \\
Y \\
Y \\
N \\
N \\
Y \\
N \\
Y \\
N\end{array}$ & $\begin{array}{l}Y \\
Y \\
N \\
Y \\
N \\
Y \\
Y \\
N \\
N \\
N \\
N\end{array}$ & $\begin{array}{c}\text { MarlyLimeston } \\
\text { Marl } \\
\text { Marl } \\
\text { Marl } \\
\text { Marly Limestone } \\
\text { Marly Limestone } \\
\text { Marl } \\
\text { Marly Limestone } \\
\text { Marly Limestone } \\
\text { Marly Limestone } \\
\text { Marly Limestone }\end{array}$ & $\begin{array}{l}\mathrm{N} \\
\mathrm{N} \\
\mathrm{N} \\
\mathrm{N} \\
\mathrm{N} \\
\mathrm{Y} \\
\mathrm{Y} \\
\mathrm{Y} \\
\mathrm{N} \\
\mathrm{N} \\
\mathrm{N}\end{array}$ \\
\hline
\end{tabular}

a The elevations are reported as a.m.s.I.

${ }^{\mathrm{b}}$ Number of horizon with permeability more than 30 Lugeon units.

${ }^{\circ} \mathrm{Y}$ : means presence, and $\mathrm{N}$ : means absent.

Note: Kowsar River Level = 505-512 m.a.s.l; Groundwater Level = 495-502 m.a.s.I. 


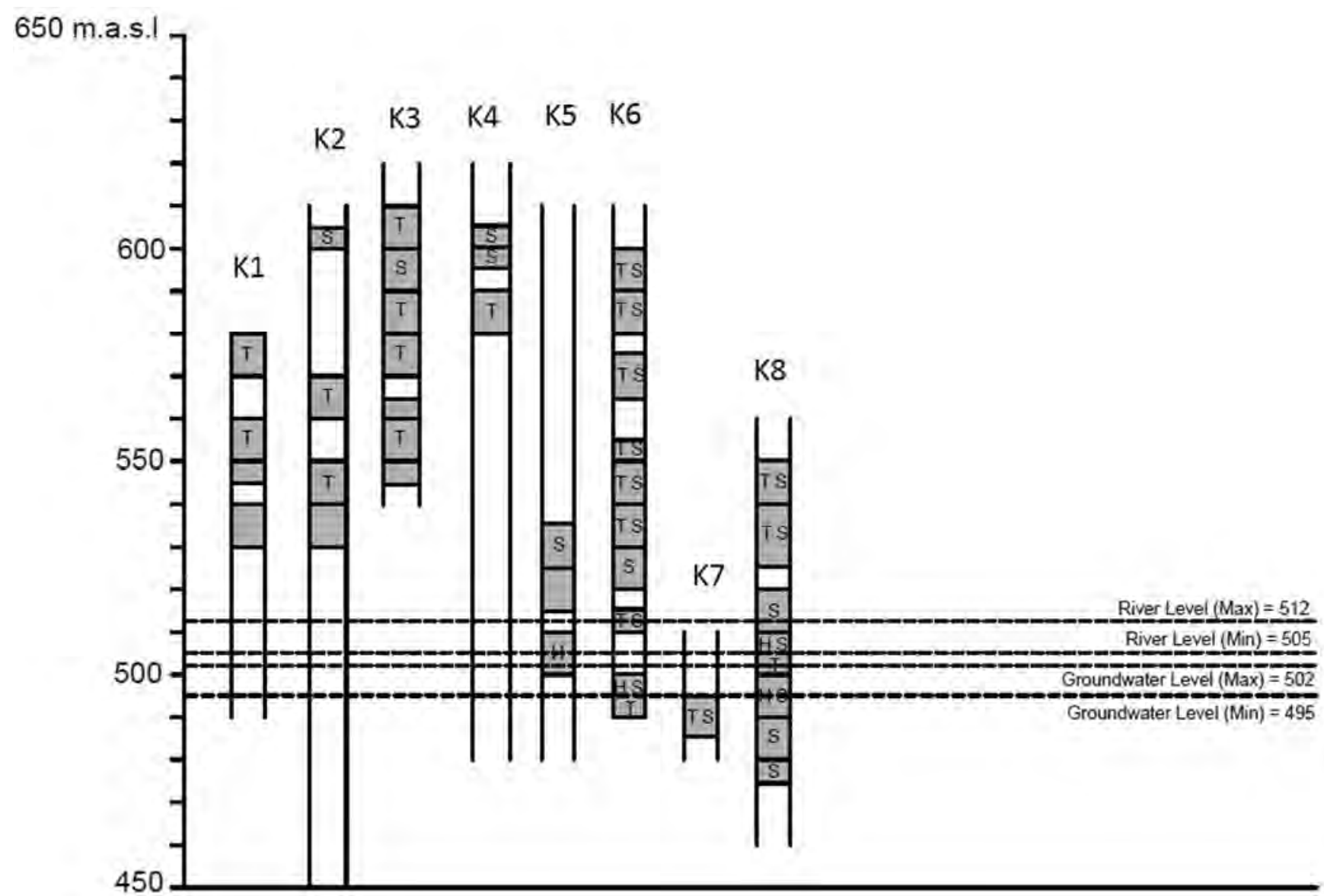

Figure 10b. Fluctuation of groundwater level and river level at boreholes in Kowsar Dam Site.

water, and then the contact of water with voids and fractured surfaces creates an opportunity for the development of some karst conduits as MSZ. Akhondi and Mohammadi (2014) have proposed a geostatistical model based on the Lugeon tests to identify spatial variability at permeability in the Tangab dam site. They concluded that the high Lugeon value placements are concordant with the marl inter-bedded layers in the left abutment of the dam. If the impermeable layers are settled as interbedded among the carbonate layer in the space between the water table and the river's bed, the role of fractures in rupturing water tightness of impermeable layer becomes effective. The karstification extension is mainly limited to river banks horizontally, and to the space between the river's bed and groundwater table vertically.

It is possible that the hydraulic connectivity between river and karstic layer is reduced if: a) insoluble materials such as clay and marl settle at the river's bed and bank to make an impermeable layer, that is, Kowsar case; b) the river has incised the karstic rocks and reached the insoluble and impermeable bedrock of karstic formation. It is apparent that in the past, there was a type of hydraulic connectivity, recharge or discharge, of river and karstic layer. In general, MSZs are mostly located at higher elevations than rivers. Determining their origin is very complex and sometimes ambiguous.

\section{Conclusion}

To show the relationship between the three main elements- fracture, stratigraphy, hydraulic, and the main seepage horizons of water in dam sites of Zagros Region, a triangular diagram was presented. The main advantage of this diagram is that it is a simple way to present the extent of the element effects on MSZ formation. There are some MSZs that cannot be related to any of the three main elements presented here. The evidence might have been removed during a geological time in different tectonical and hydrogeological conditions from the present.

Although the Asmari Formation is inherently fractured, according to the distribution of boreholes and dams on the diagram, there is no borehole or dam in which only one element is responsible for creating MSZ. In fact, karst development is a very complicated process, which is not merely governed by interaction of these elements. In summary, Asmari, as a carbonate rock, is soluble but the impermeable layers' settlements (thin layer marly, marly limestone, and clay limestone) inside the formation make some horizons to be prone to conduit development and guide the water to seep from the area. 
The hydraulic connectivity of the river with adjacent karstic layers and groundwater level fluctuation zones are very important in developing an MSZ. The gaining rivers are effective in the development of a MSZ at river level and long distances from the river. The water seepage is expected to be more problematic in dam abutments than basements. The recharge rivers widen fractures and dissolve rocks at their basements. The high hydraulic gradient and massive volumes of concentrated water in the space between the river's bed and groundwater level can breach the impermeable interbeds. The main problem with this type of dam is in the foundation.

Although in neutral rivers, there is no hydraulic relationship between river and carbonate rocks, existence of the MSZ shows that there may be some hydraulic relations at some points in the past. This type is a very complex MSZ development.

Finally, at the borehole scale, it is possible to determine a MSZ to be controlled by one of the three mentioned elements. To extend the results at dam site or regional scale, it is necessary to have more information on regional geology and dye-tracing data.

\section{References}

Aghanabati, A., 2004, Geology of Iran: Geological Survey of Iran, p. 619. [Persian]

Akhondi, M., and Mohammadi, Z., 2014, Preliminary analysis of spatial development of karst using geostatistical simulation approach: Bulletin of Engineering Geology and the Environment, v.73, p.11. https://doi.org/10.1007/s10064-014-0599-3.

Alavi, M., 2004, Regional stratigraphy of the Zagros Folds-Thrust Belt of Iran and its proforeland evolution: American Journal of Science, v. 304, p. 1-20. https://doi.org/10.2475/ajs.304.1.1.

Ashjari, J., 2007, Classification of Zagros karstic aquifers based on general direction of groundwater flow and physico-chemical properties: [Ph.D. Dissertation]: Shiraz, Iran, University of Shiraz, Iran.

Ashjari, J., Raeisi, E., 2006, Influences of anticlinal structure on regional flow, Zagros, Iran: Journal of Cave and Karst Studies, v. 68, n. 3, p. 118-129.

Cooper, A.H., Gutiérrez, F., 2013, Dealing with gypsum karst problems: hazards, environmental issues, and planning, in Shroder, J. and Frumkin, A., eds., Treatise on Geomorphology: Karst Geomorphology, San Diego, Academic Press, v. 6, p. 451-462.

Falcon, N.L., 1974, Southern Iran: Zagros Mountains: Geological Society, London, v. 4, p. 199-211.

Ford, D.C., and Ewers, R.O., 1978, The development of limestone cave systems in the dimensions of length and depth: Canadian Journal of Earth Science., v. 15, p. 1783-1798. https://doi.org/10.1139/e78-186.

Ford, D.C. and Williams, P., 1989, Karst Hydrogeology and Geomorphology: London, Chapman \& Hall, 570 p.

Gutiérrez, F., Desir, G., Gutiérrez, M., 2003, Causes of the catastrophic failure of an earth dam built on gypsiferous alluvium and dispersive clays (Altorricón, Huesca Province, NE Spain): Environmental Geology, v. 43, p. 842-851. https://doi.org/10.1007/978-94-011-7778-8.

Gutiérrez, F., Parise, M., De Waele, J., Jourde, H., 2014, A review on natural and human-induced geohazards and impacts in karst: Earth-Science Reviews, v. 138, p. 61-88. https://doi.org/10.1016/j.earscirev.2014.08.002.

Gutiérrez, F., Mozafari, M., Carbonel, D., Gómez, R., Raeisi, E., 2015, Leakage problems in dams built on evaporites. The case of La Loteta Dam (NE Spain), a reservoir in a large karstic depression generated by interstratal salt dissolution: Engineering Geology, v. 185, p. $139-154$.

Houlsby, A.C., 1976, Routine interpretation of the Lugeon water-test: Quarterly Journal of Engineering Geology and Hydrogeology, v. 9, $303-313$. https://doi.org/10.1144/GSL.QJEG.1976.009.04.03.

James. AN., 1992, Soluble material in civil engineering: Chichester, U.K., Ellis Horwood, 300 p.

Johnson, K.S., 2008, Gypsum-karst problems in constructing dams in the USA: Environmental Geology, v. 53, p. 945-950. https://doi. org/10.1007/s00254-007-0720-z.

Karimi, H., Raeisi, E., Zare, M., 2005, Physicochemical time series of karst springs as a tool to differentiate the source of spring water: Carbonates and Evaporites, v. 20, no. 2, p. 138-147. https://doi.org/10.1007/BF03175457.

Kiraly, L., 1975, Rapport sur l'état actual des connaissances dans le domaine des caractères physiques des roches karstiques, in Bueger and Dubertret, eds., International Union of Geological Sciences, Series B. 3, p.53-67.

Lowe, D.J, 1992, The origin of limestone caverns: an inception horizon hypothesis, [Ph.D. Dissertation]: Manchester, U.K., Manchester Metropolitan University, $511 \mathrm{p}$.

Milanović, P.T., 2000, Geological Engineering in Karst: Dams, Reservoirs, Grouting, Groundwater Protection, Water Tapping, Tunneling: Belgrade, Zebra, $347 \mathrm{p}$.

Milanović, P.T., 2002, The environmental impacts of human activities and engineering constructions in karst regions: Episodes, v. 25, p. 13-21.

Milanović, P.T., 2004, Water Resources Engineering in Karst: Boca Raton, Fla., CRC Press, 328 p. https://doi.org/10.1201/9780203499443.

Milanović, P., 2011, Dams and Reservoirs in Karst, in van Beynen, P., eds., Karst Management: Dordrecht, Springer. https://doi.org/10.1007/97894-007-1207-2_3.

Palmer, A.N., 1975, The origin of maze caves: Bulletin of the National Speleological Society, v. 37, p. 57-76.

Palmer, A.N., 1991, The origin and morphology of limestone caves: Geological Society of America Bulletin, v. 103, p. 1-21. https://doi.org/10.113 0/0016-7606(1991)103<0001:OAMOLC>2.3.CO;2.

Palmer, A.N., 2007, Cave Geology: Trenton, N.J., Cave Books, National Speleological Society, 454 p.

Parise, M. and Gunn, J., 2007, Natural and anthropogenic hazards in karst areas: Recognition, Analysis and Mitigation, Geological Society of London, Special Publication 279.

Parise, M. and Lollino, P., 2011. A preliminary analysis of failure mechanisms in karst and man-made underground caves in Southern Italy: Geomorphology, v. 134, nos. 1-2, p. 132-143. https://doi.org/10.1016/j.geomorph.2011.06.008.

Parise, M., Closson, D., Gutiérrez, F., Stevanović, Z., 2015, Anticipating and managing engineering problems in the complex karst environment: Environmental Earth Sciences, v. 74, p. 7823-7835. https://doi.org/10.1007/s12665-015-4647-5.

Rahanjam, M., 2009, Modeling of water loss potential in future of Tang Douk Dam due to dissolution [M.Sc. Thesis]: Tehran, Iran, Tehran University. [Persian]

Romanov, D., Gabrovšek, F., Dreybrodt, W., 2003, Dam sites in soluble rocks: a model of increasing leakage by dissolutional widening of fractures beneath a dam: Engineering Geology, v. 70, P. 17-35. 
Shabab-Boroujeni, B., 2012, Determination of effective factors on permeability in karstic dams in west of Zagros [M.Sc. Thesis]: Tehran, Iran, Tehran University. [Persian]

Stevanović, Z., 2015, Karst Aquifers - Characterization and Engineering: Cham, Switzerland, Springer, 692 p. https://doi.org/10.1007/978-3319-12850-4.

Stocklin, J., Setudehnia, A., 1971, Stratigraphic Lexicon of Iran: Geological Survey of Iran Report 18-1971.

Water Research Centre of Iran, 1997, Tracing studies of Kowsar (Tang e Douk) Dam Site: Behbahan, p. 35-37. [Persian]

White, W.B., 1988, Geomorphology and Hydrology of Karst Terrains: New York, Oxford University Press, 464 p.

Wright, V.P. (1991) Paleokarst types, recognition, controls and associations: In: Wright, V.P., ed., Paleokarsts and Paleokarstic Research Institute of Sedimentology, Occassional Publication Series, v. 2, p. 56-88.

Zhou, W., and Beck, B.F., 2011, Engineering issues on karst, in Van Baynen, P.E., ed., Karst Management. Springer, Dordrecht, p. 9-45. https:// doi.org/10.1007/978-94-007-1207-2_2. 